\title{
Future Prospects of Soybean in Pakistan
}

\author{
Zahid Akram* and Qadeer Ahmad \\ Department of Plant Breeding and Genetics, Pakistan \\ *Corresponding author: Zahid Akram, Department of Plant Breeding and Genetics, Pakistan
}

\begin{tabular}{|c|c|}
\hline ARTICLE INFO & ABSTRACT \\
\hline Received: February 10, 2019 & Citation: Zahid Akram, Qadeer Ahmad. Future Prospects of Soybean in Pakistan. Biomed J \\
\hline Published: March 11, 2019 & Sci \& Tech Res 15(4)-2019. BJSTR. MS.ID.002743. \\
\hline
\end{tabular}

\section{Case Report}

Pakistan is an agriculture country. Majority of Pakistan's population is dependent upon Agriculture and agricultural products. Pakistan is spending a lot of money on the edible oil import. The import bill of edible oil was Rs.284.546 billion (US\$ 2.710 billion) [1]. Globally soybean is grown on an area of 120.48 million hectares but in Pakistan total area under soybean cultivation is comparatively less [2]. Farmers are getting low crops production due to these reasons like non-availability of good quality seeds, lack of advanced agricultural mechanization techniques and unavailability of modern methodologies which are applied in commercial crop production to save time and enhancement yield. Value addition is good techniques in which raw materials is converted into usable products e.g. Potato is value added in different products like processed Chips, finger chips etc. But our farmers are unaware about the value addition of products to get maximum profit [3]. Soybean is an important oil seed crop. It contains $20 \%$ oil content and $40 \%$ protein. It is considered as world healthiest food ever. Increased protein intake such as soybean meal has always been associated with suppression of appetite.

Soybean has been historically called as "meat of the field" or "meat without bones" due to these reasons it is highly rich in protein content. Genistein (an isoflavone phytonutrient in soybean) is used for cancer-prevention. One cup of soybean (172 g) contains 298 calories and copper (78 \%) manganese (71\%) phosphorus (60\%), iron $49 \%$ omega-3 fats (43\%) fiber (41\%), magnesium (37\%), vitamin K (37\%),potassium (25\%) [4]. It is a leguminous crop that is grown to fix nitrogen in soil to increase the fertility of soil through Rhizobacteria. Due to its low production it is grown on a very low area of Pakistan. Value added products of soybean include soymilk, soy flour, soy protein and tofu etc. Early planting of soybean is a critical factor in maximizing yield potential, if crop production technology is followed. Early planting of soybean crop can help to develop a large canopy, which may lead to an increase in photosynthesis, resulting in extension of the reproductive growth stage, ultimately increasing the yield potential [5]. Now days we are facing the problem of climate change throughout the world. Due to this factor environmental temperature has been changed. It is affecting badly the production of all crops due to shortage of water. So, it is need to grow such alternate crops that can survive on low water availability.

So, soybean is a crop which can thrive in all conditions. It has deep root system and can survive under less water availability. It is therefore high time to realize the fact that Pakistan is spending a lot of foreign exchange for the import of edible oil to meet the local demands. We should look for some alternate sources of edible oil from our own sources. We have fortunately good fertile lands and hardworking farming community which can be engaged for growing crops having good potential of edible oil like soybean. Government should provide good quality seed of soybean varieties at affordable prices to the farmers so that they can plant this seed in their more productive areas rather than marginal lands. Government should also fix support price to this crop and arrange to purchase the farmers produce at such price so that maximum farmers can be attracted towards its cultivation. If these suggestions are followed it is hoped that we can bridge the gap between our edible oil demand and supply.

\section{References}

1. Anonymous (2015) Agriculture Statistics of Pakistan, Ministry of Food, Agriculture and Livestock, p. 65-66.

2. FAO (2017) Trade and Market Division, Food Outlook: Oilseeds, Oils and Meals, p. 1-16. 
3. Masuda T, PD Goldsmith (2009) World soybean production: area harvested, yield, and long-term projections. International Food Agribusiness Management Rev 12(4): 143-162.

4. Anwar FG, M Kamal, F Nadeem, G Shabir (2016) Variation of quality characterestics among oils of different soybean varieties. J King Saud University 28: 332-338.

\section{ISSN: 2574-1241}

DOI: 10.26717/BJSTR.2019.15.002743

Zahid Akram. Biomed J Sci \& Tech Res

(C) This work is licensed under Creative By Commons Attribution 4.0 License

Submission Link: https://biomedres.us/submit-manuscript.php
5. Shahid MQ, MF Saleem, HZ Khan, SA Anjum (2009) Performance of soybean (Glycine max L.) under different phosphorus levels and inoculation. Pakistan J Agriculture Science 46(4): 1-4.

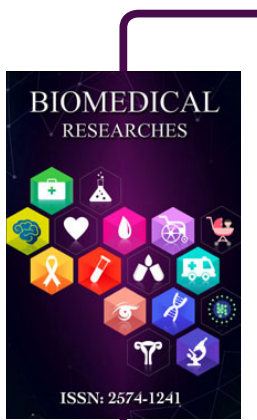

Assets of Publishing with us

- Global archiving of articles

- Immediate, unrestricted online access

- Rigorous Peer Review Process

- Authors Retain Copyrights

- Unique DOI for all articles 